\title{
AKURASI DALAM JURNALISME WARGA PADA RADIO SUARA SURABAYA
}

\author{
Desi Yoanita $^{1^{*}}$; Fanny Lesmana ${ }^{1}$ \\ ${ }^{1}$ Program Studi Ilmu Komunikasi, Fakultasa Ilmu Komunikasi, Universitas Kristen Petra \\ Jalan Siwalankerto 121-131, Surabaya 60236, INDONESIA \\ * Korespondensi penulis, e-mail: dy-nita@petra.ac.id
}

\begin{abstract}
ABSTRAK
Akurasi merupakan konsep yang sangat signifikan bagi sebuah institusi media massa, khususnya bagi media massa yang menyediakan ruang untuk jurnalisme warga. Radio Suara Surabaya menjaga akurasi dalam penyampaian informasi oleh jurnalis warga dengan cara klarifikasi, menurunkan reporter SS sendiri dan memiliki gatekeeper. Pola menyaring informasi yang dilakukan gatekeeper membuat para jurnalis warga belajar bagaimana melaporkan informasi dengan standar jurnalistik yang benar. Penelitian ini dilakukan dengan metode studi kasus dan menggunakan teknik pengumpulan data berupa wawancara dan observasi. Dari penelitian ini didapati, Radio Suara Surabaya melakukan tiga cara untuk mempertahankan akurasi informasi dari para jurnalis warga, yaitu: melakukan klarifikasi pada sumber yang kompeten, menugaskan reporter ke lapangan, dan membentuk tim gatekeeper untuk menjadi filter.
\end{abstract}

Kata kunci: Akurasi; jurnalisme warga; radio.

\begin{abstract}
Accuracy is a very significant concept for mass media, particularly the mass media that provides space for citizen journalism. Radio Suara Surabaya maintain accuracy in the delivery of information by citizen journalists by way of clarification, lowering the SS reporter alone and have gatekeepers. The pattern of information filtering which is done by gatekeepers make citizen journalists learn how to report the information to the proper journalistic standards.This research was conducted using the case study method and data collection techniques such as interviews and observations. The result of this research found that Radio Suara Surabaya do three ways to maintain the accuracy of information from citizen journalists, namely: clarify to the competent sources, assigning reporters to the field, and create a gatekeeper team to be the filter.
\end{abstract}

Keywords: Accuracy; citizen journalism; radio.

\section{PENDAHULUAN}

Radio Suara Surabaya (SS) merupakan salah satu media massa mainstream yang lahir pada 11 Juni 1983 dan berkembang di Surabaya. SS merupakan stasiun radio yang memadukan antara siaran kata dan siaran hiburan, berupa program musik.

Berangkat dari salah satu tujuan media massa, yakni menyajikan informasi, SS memposisikan diri sebagai stasiun radio yang menyediakan informasi untuk kepentingan warga, khususnya di kota Surabaya. SS menjadi radio swasta pertama di Indonesia yang berkonsep radio informasi (BH, 2010, p. vii). Informasi yang menjadi prioritas bagi Radio Suara Surabaya adalah masalah lalu lintas, yang memang merupakan salah satu problem besar bagi masyarakat kota Surabaya.
Sebagaimana media massa mainstream, SS memiliki reporter untuk menyampaikan informasi kepada khalayaknya. Namun pada tahun 1994, SS mengembangkan siaran interaktif berbasis jurnalistik $(\mathrm{BH}$, 2010 , p. vii). SS menggagas adanya partisipasi warga dalam melaporkan peristiwa yang ada kepada penyiar radio yang sedang bertugas.

SS memang bukan satu-satunya stasiun radio yang menggunakan partisipasi warga dalam mengumpulkan informasi. Namun, di Surabaya, SS merupakan pionir dalam melibatkan partisipasi warga dalam penyampaian informasi. Pertanyaannya, apakah informasi yang disampaikan oleh warga dapat dipercaya kebenarannya?

Dalam hal pengumpulan data, seorang jurnalis atau reporter pada umumnya dibekali dengan konsep 
jurnalistik. Demikian pula halnya dengan reporter SS. Tidak hanya memeroleh konsep jurnalistik untuk bekal dalam pekerjaannya, beberapa orang reporter malah memiliki latar belakang pendidikan dari jurusan ilmu komunikasi atau ilmu publisistik. Dengan demikian, informasi yang diperoleh para reporter boleh dikatakan dapat dipertanggungjawabkan kebenarannya. Bagaimana halnya dengan para pendengar yang melaporkan sebuah informasi melalui SS?

Tentu saja tidak semua pendengar yang melaporkan informasi adalah mereka yang pernah mendapatkan bekal perihal ilmu jurnalistik. Artinya, tidak semua dari pendengar mengetahui konsep pelaporan sebuah informasi kepada khalayak melalui media massa, dalam hal ini adalah radio.

Radio sebagai media massa tentu saja dapat menyampaikan informasi berupa berita, yang termasuk di dalam siaran kata. Prayudha (2006, p. 49) menyebutkan berita merupakan salah satu jenis siaran kata yang disampaikan melalui radio. Oramahi (2003, p. 3) menegaskan bahwa berita harus memiliki relevansi dengan pendengar. Jika demikian halnya, maka sebuah informasi atau berita haruslah akurat. Sebab, jika informasi yang disampaikan sebuah media massa - dalam hal ini adalah radio - tidak akurat, maka hal tersebut dapat menimbulkan ketidakpercayaan pendengar terhadap media massa yang bersangkutan. Hal ini tentu berdampak pada reputasi media tersebut, dan nantinya berujung pada kelangsung hidupnya. Media yang ditinggalkan audiensnya tentu tidak akan bertahan lama.

Isu akurasi dan objektivitas informasi ini membuat jurnalisme warga masih dalam ranah pro dan kontra, bahkan di kalangan akademisi maupun praktisi jurnalistik. Sebuah penelitian yang dilakukan oleh Bolette B. Blaagaard (2013) menunjukkan bahwa mahasiswa international journalism di sebuah universitas di London memandang jurnalisme warga sebagai salah satu alat jurnalistik untuk menemukan angle dan sumber. Artinya, mereka menempatkan jurnalisme warga hanya sebagai bagian dari jurnalisme tradisional, dan tidak mengakuinya sebagai praktik jurnalistik. Sebagian mahasiswa yang dilibatkan dalam focus group discussion, mendukung edukasi tentang prinsip-prinsip jurnalistik kepada publik agar informasi yang disampaikan oleh para jurnalis warga memenuhi kaidah jurnalistik profesional. Mereka berpendapat, seorang jurnalis warga tidak akan bisa menjadi profesional jika tidak memiliki kemampuan, pengetahuan, dan sumber terpercaya.
Penelitian serupa juga pernah dilakukan kepada pimpinan redaksi 29 surat kabar kecil di Texas. Hasilnya, sebagian secara terang-terangan menolak konsep jurnalisme warga karena dianggap tidak sesuai dengan proses produksi sebuah media. Mereka beranggapan, berita yang disampaikan kepada audiens harus diproduksi oleh seorang jurnalis profesional. Apalagi, ketika mereka mencoba menerima tulisan yang dihasilkan oleh seorang jurnalis warga, mereka merasa kualitasnya masih jauh dari standar jurnalisme yang ideal. Meskipun ada yang tidak setuju dengan konsep jurnalisme warga, ada juga sebagian pimpinan redaksi yang mendukung jurnalisme warga. Menurut mereka, jurnalisme warga membantu media menjadi lebih dekat dengan masyarakat. Selain itu, keberadaan jurnalisme warga juga sangat membantu media yang memiliki keterbatasan sumber daya manusia dan anggaran (Lewis, Kaufhold, \& Lasorsa, 2009, p. 16).

Di Indonesia sendiri, jurnalisme warga merupakan salah satu perwujudan hak seorang warga negara untuk menyampaikan informasi dengan menggunakan segala jenis saluran yang tersedia (UndangUndang Dasar Negara Republik Indonesia tahun 1945 pasal 28F).

Dalam fenomena yang terjadi SS, sebagian dari informasi yang disampaikan melalui radio diperoleh dari partisipasi warga yang tidak banyak memahami konsep jurnalistik. Melalui program siaran bertajuk Kelana Kota, SS membuka kesempatan 24 jam bagi masyarakat untuk menyampaikan informasi yang mereka miliki. Dari sini timbullah sebuah pertanyaan, apakah informasi atau berita yang disampaikan sudah akurat?

\section{TINJAUAN PUSTAKA}

\subsection{Berita di Media Radio}

Radio telah menjadi media massa yang ada di segala tempat dan di sepanjang waktu. Sejak kemunculannya, radio sudah diyakini akan menjadi media informasi yang bersifat massal (Fang, 1997, p. 163). Sejak kehadiran televisi, radio mulai mengarahkan informasinya pada berita-berita lokal yang jarang disentuh oleh televisi (Rivers, dkk, 2004, p. 222).

Menurut Oramahi (2003, pp. 2-3), berita yang banyak diminati oleh pendengar radio adalah berita yang menyangkut kepentingan mereka, atau yang memiliki dampak langsung pada mereka. 
Radio Suara Surabaya (SS) yang merupakan media siaran lokal di Surabaya juga mengarahkan informasinya pada berita lokal karena menyangkut kepentingan mereka, maupun memiliki dampak langsung kepada mereka.

\subsection{Akurasi Berita}

Akurasi bicara tentang kecenderungan jurnalis yang menitikberatkan pada objektivitas tentang sebuah berita. Akurasi terkait dengan prinsip etika bagi para jurnalis di dalam menjalankan pemberitaan (Franklin, dkk, 2005, p. 6).

Akurasi berbicara tentang ketepatan; ketepatan nama narasumber, angka, tanggal, usia juga dalam hal detail penyampaian fakta. Kusumaningrat dan Kusumaningrat $(2005$, p. 48) menyebutkan bahwa pembaca sangat memperhatikan perihal akurasi.

Kode etik yang dikeluarkan oleh Society Profesional Journalist di Amerika menyatakan bahwa seorang jurnalis seharusnya menguji akurasi informasi dari semua sumber dan latihan untuk menghindari kelalaian (Rich, 2004, p. 91). Sedangkan di Indonesia, dalam Kode Etik Jurnalistik pasal 3 ayat 2 menyebutkan "Wartawan Indonesia meneliti kebenaran sesuatu berita atau keterangan sebelum menyiarkannya, dengan juga memperhatikan kredibilitas sumber berita yang bersangkutan".

Hal ini menunjukkan bahwa akurasi berkaitan dengan kepercayaan dari khalayak. Jika sebuah media menyampaikan informasi yang tidak akurat, maka media massa tersebut tidak akan dipedulikan.

\subsection{Jurnalisme Warga}

Jurnalisme warga merupakan sebuah konsep yang meliputi audiens dalam melaporkan serta menyebarkan berita. Konsep ini timbul sebagai upaya media massa dalam meningkatkan interaksi media dengan pembaca. Kontributornya disebut jurnalis warga (Rich, 2010, p. 26).

Keberadaan jurnalisme warga ini membuat orang semakin tertantang untuk mengirimkan pelbagai informasi yang dekat dengan lokasi tempat tinggal mereka maupun aktivitas yang terjadi di sekitar mereka kepada media yang menyediakan sarana jurnalisme warga (Abdullah dalam Bajari dan Saragih, 2011, p. 468).

Pelaku jurnalisme warga adalah warga biasa yang tidak memiliki latar belakang pendidikan jurnalistik atau komunikasi. Menurut Quinn \& Lamble (2008), kualitas jurnalisme warga pada dasarnya tidak akan bisa sama seperti pada media-media konvensional. Dalam hal ini faktor yang terlihat paling beda adalah masalah akurasi dan subjektivitas.

Salah satu kritik yang dilontarkan dalam kaitan dengan keberadaan jurnalisme warga adalah akurasi data, baik dalam penyebutan nama, lokasi, waktu kejadian, kronologis dan lain-lain (Abdullah dalam Bajari dan Saragih, 2011, p. 474). Karenanya, dalam penelitian ini, akurasi dalam praktik jurnalisme warga pada praktik penyampaian informasi di Radio Suara Surabaya.

\section{METODOLOGI}

Metode yang dipergunakan dalam melakukan penelitian ini adalah studi kasus. Menurut Pawito (2007, p. 140-141), studi kasus merupakan suatu metode ilmiah yang lazim diterapkan untuk memberikan penekanan pada spesifikasi dari kasus yang diteliti. Penelitian ini merupakan penelitian studi kasus tunggal (single case) karena fenomenanya terjadi pada satu subjek saja (Nock, Michel, Photos, 2007, p. 337).

Dalam penelitian ini, hal yang diangkat sebagai bahan kajian adalah sebuah institusi, yakni Radio Suara Surabaya. Sebagai radio profesional pertama di Surabaya yang berkonsep interaktif dan membuka ruang seluas-luasnya bagi warga untuk menyampaikan informasi (jurnalisme warga), peneliti tertarik mengkaji bagaimana SS mempertahankan akurasi informasi-informasi tersebut.

Dalam metode studi kasus ini diperlukan informan untuk melihat bahan kajian lebih dalam dan menyeluruh. Informan utama dalam penelitian ini adalah Direktur Operasional Radio Suara Surabaya. Adapun teknik pengumpulan data dilakukan dengan wawancara mendalam dan observasi lapangan.

\section{HASIL DAN PEMBAHASAN}

Sebagai sebuah institusi media massa, Radio Suara Surabaya (SS) wajib menjalankan fungsinya untuk menyampaikan informasi kepada pendengar selaku khalayak media. Informasi tersebut tidak hanya dikumpulkan oleh para reporter SS, melainkan juga berdasarkan laporan yang diterima dari pendengar.

Pada tahun 2009, SS mencatat ada sekitar 329 ribu pendengar setia. Setiap hari, setiap minggu atau 
minimal sebulan sekali, para pendengar itu akan menyampaikan berbagai informasi. Informasi yang mereka laporkan terkait masalah lokal yakni kemacetan lalu lintas, peristiwa yang terjadi di jalan raya, maupun kebijakan pemerintah kota $(\mathrm{BH}, 2010$, p. 61). Para jurnalis warga ini jelas tidak selalu memiliki bekal dalam pemahaman nilai-nilai jurnalistik. Meski demikian, tidak berarti SS mengabaikan prinsip akurasi dalam pengelolaan informasinya.

"Ruang publik itu punya inisiatif dan mereka merasakan mereka bisa melakukan itu. Kami tidak pernah menyuruh mereka lapor. Tapi karena peristiwa malam banjir itu, orang jadi belajar, oh bisa laporan di SS, soalnya kita bisa ngomong langsung," ujar Jonathan.

Menariknya, SS tidak pernah mengadakan training untuk pendengar tentang apakah jurnalistik itu, bagaimana cara meliput dan menyebarkan informasi di media. Menurut Jonathan, ia merasakan publik (pendengar) sepertinya belajar sendiri tentang bagaimana cara menyampaikan laporan serta tentang apa yang dilaporkan. Menurutnya, pola editing yang selama ini dilakukan oleh gatekeeper SS sepertinya ditangkap oleh khalayak SS.

SS memiliki gatekeeper yang akan menyeleksi atau menyunting informasi yang disampaikan oleh pendengar. Hal itulah yang lambat laun dipelajari oleh pendengar SS. Setelah 18 tahun sejak pertama kali menerima telepon dari pendengar, kini pendengar SS sendiri mulai memahami bagaimana seorang 'reporter' seharusnya melaporkan informasi, terlebih khusus melaporkan dengan pola $5 \mathrm{~W}+1 \mathrm{H}$.

Di sisi lain, Jonathan mengakui ada pula pendengar yang tidak mau belajar. Ada yang menyampaikan fakta tidak akurat sehingga ada beberapa penelepon (pendengar) yang sudah diberi catatan khusus oleh tim gatekeeper sehingga tidak bisa on air. Artinya, informasi yang diberikan hanya akan sampai ke gatekeeper, selanjutnya gatekeeper akan mengolah dan menyampaikannya ke penyiar. Ada pula yang di tengah laporan on air terpaksa dipotong oleh penyiar, karena isi pesannya dianggap melanggar kaidah etika jurnalistik atau moral. Namun ada pula yang memang di-black list karena meskipun sudah berkali-kali diberitahu tapi tidak memahami dan tidak mengalami perubahan.

Radio Suara Surabaya (SS) merupakan salah satu media massa lokal di Surabaya yang sangat mem- perhatikan pentingnya akurasi. Dewabrata (2004) mengingatkan, media massa yang berulang kali menyajikan berita tidak akurat akan kehilangan reputasi serta kehilangan kepercayaan khalayaknya. Lambat laun media yang seperti itu akan ditinggalkan khalayaknya.

Terkait masalah akurasi dalam etika jurnalistik, SS merasakan perlunya klarifikasi terhadap setiap laporan yang masuk dari warga. Klarifikasi ini dilakukan terhadap pihak yang dilaporkan maupun terhadap sumber yang dianggap kompeten. Tidak dapat dipungkiri, jurnalis warga acapakali menyampaikan informasi yang hanya terkait pada sudut pandang pribadi warga yang melapor.

Jonathan menegaskan bahwa SS melakukan klarifikasi pada petugas lalu lintas, dinas perhubungan maupun siapa saja yang terlibat dalam pembuatan regulasi, jika ada komplain yang terkait dengan kondisi jalan raya dan lalu lintas.

Karena pentingnya prinsip akurasi, SS tetap memfungsikan reporternya sendiri untuk melakukan check and recheck ketika ada informasi yang dianggap penting dan berskala besar. "Bila peristiwanya besar dan membutuhkan pendalaman-pendalaman, maka kita langsung kontak wartawan untuk tugas ke sana." Namun tentunya reporter-reporter SS tidak boleh sekadar menghasilkan berita straight news, karena berita macam itu sudah menjadi makanan sehari-hari pendengar yang jumlahnya mencapai ratusan ribu. Akhirnya dikeluarkanlah kebijakan, reporter SS harus masuk ke ranah in depth reporting, atau investigative news. "Intinya adalah mereka tidak lagi ke straight news. Jadi kalau mereka reportase, kita menuntutnya perlu ada pendalaman. Itu yang tidak mungkin dilakukan pendengar."

Untuk mengantisipasi masalah akurasi ini, SS memiliki sebuah divisi penting yang dinamakan gatekeeper. Nurudin (2007) menyebutkan salah satu ciri khas komunikasi massa adalah dikontrol oleh gatekeeper. Gatekeeper adalah orang atau pihak yang sangat berperan dalam penyebaran informasi melalui media massa. Gatekeeper yang dimaksud antara lain pimpinan redaksi, wartawan dan editor. Informasi yang berasal dari media massa telah terlebih dahulu diseleksi oleh gatekeeper apakah informasi tersebut layak atau tidak untuk disebarkan. Jika dalam media profesional yang semua jurnalisnya profesional saja diperlukan gatekeeper untuk menyunting atau memfilter informasi sebelum disampaikan ke khalayak, apalagi untuk sebuah media profesional yang menerima laporan informasi dari jurnalis warga. 
Di SS, mayoritas penyiar umumnya juga merangkap sebagai gatekeeper. Karena penyiar memiliki pengalaman sebagai gatekeeper, pada saat on air, ia bisa memberikan tanggapan kepada pendengar seperti ketika ia menjadi gatekeeper. Ia tahu kriteria informasi yang dibutuhkan pendengar SS. Sebaliknya, ketika seorang gatekeeper juga adalah penyiar, ia paham informasi seperti apa yang menarik untuk disiarkan. Karena sama-sama siaran dan menjadi gatekeeper, masing-masing individu bisa mengerti kebutuhan dan kesulitannya. Gatekeeper itu yang sebetulnya menjadi penyaring dengan standar-standar jurnalistik."

Apabila informasi yang disampaikan oleh jurnalis warga dianggap rawan, SS akan menurunkan reporternya sendiri (wawancara Dani, penyiar). Salah satu informasi yang dianggap rawan adalah ketika ada laporan dari pendengar di Mojokerto terkait adanya bom di malam Natal. SS bukanlah media massa pertama yang memberitakan informasi tersebut karena SS mementingkan akurasi. SS melakukan konfirmasi dengan Polda Jatim yang dianggap sebagai sumber kompeten untuk mengetahui kebenaran informasi tersebut (wawancara Jonathan). Setelah mendapatkan konfirmasi, maka 30 menit kemudian SS menyiarkan informasi tersebut.

Berkaitan dengan masalah akurasi itulah, SS tidak membiarkan semua pendengar yang memberikan laporan untuk on air secara langsung. Misalnya ada laporan dari warga tentang listrik padam, SS tidak langsung menyiarkannya, namun terlebih dahulu melakukan konfirmasi ke Perusahaan Listrik Negara (PLN), menanyakan apakah ada gangguan atau pemadaman bergilir.

Skema laporan jurnalis warga hingga disiarkan di Radio Suara Surabaya seperti pada Gambar 1.

Ada dua kriteria informasi agar bisa mengudara. Pertama, memenuhi kriteria news value, di antaranya kebaruan dan proximity. Kedua adalah adanya news judgement, yakni berita tersebut berdampak (wawancara Dani). Sementara itu Wismanti, penyiar senior SS yang juga gatekeeper menambahkan kriteria informasi yang bisa diterima adalah yang sesuai dengan target pendengar Radio SS (SES B, A, hingga A+) dan tidak mengandung SARA (wawancara Wismanti). Setiap gatekeeper maupun penyiar di SS wajib memahami dan menjalankan kriteria-kriteria itu saat menerima informasi dari pendengar.

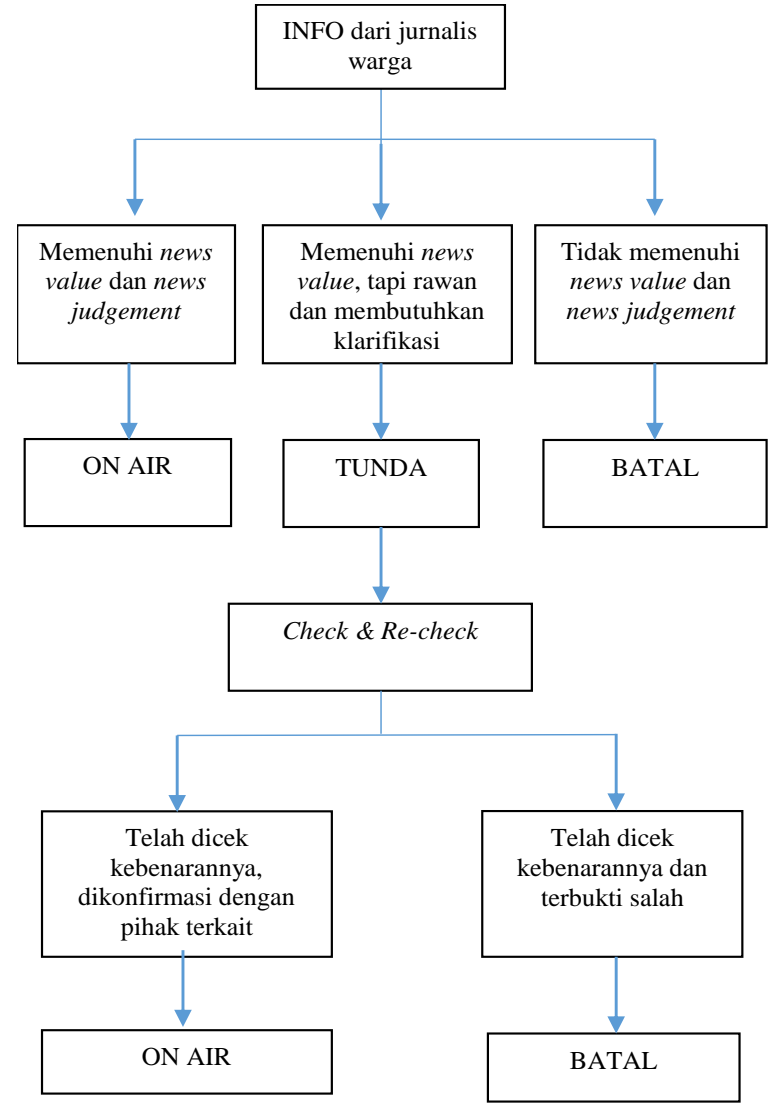

Gambar 1. Alur laporan jurnalis warga hingga disiarkan di Radio Suara Surabaya

Fungsi gatekeeper di Radio SS sangat krusial, karena merekalah yang memilah benar tidaknya sebuah laporan; layak on air atau tidak; perlu klarifikasi atau tidak. Bahkan menurut Errol, gatekeeper di Radio SS perannya bisa dikatakan seperti sutradara sekaligus produser. Para gatekeeper selain saling berkoordinasi, juga harus selalu berkomunikasi dengan penyiar yang sedang on air.

Selain gatekeeper sebagai palang pintu pertama, penyiar tetap merupakan sosok penting di Radio SS. "Karena itu buat kami semua orang di SS dalam konsep siaran, itu adalah bukan sekadar broadcaster, mereka adalah jurnalis," ujar Errol.

Karena merangkap, penyiar memiliki pengalaman sebagai gatekeeper, pada saat on air, ia bisa memberikan tanggapan kepada pendengar seperti ketika ia menjadi gatekeeper. Ia tahu kriteria informasi yang dibutuhkan pendengar SS. Sebaliknya, ketika seorang gatekeeper juga adalah penyiar, ia paham informasi seperti apa yang menarik untuk disiarkan. "Kalau displit, ini nggak akan jadi seperti ini. Karena anda di gatekeeper, saya di on air. Saya nggak punya pengalaman itu, anda nggak punya pengalaman 
siaran, sama-sama nggak bisa mengerti kebutuhan dan kesulitan masing-masing itu apa sebenarnya." Keuntungan rangkap posisi ini juga dirasakan karena kerapkali informasi-informasi yang dilaporkan merupakan informasi yang berkelanjutan.

Diakui oleh Errol Jonathans, SS sering menerima informasi yang keliru atau opini yang sangat subjektif. Jika jurnalisme warga ini diproduksi oleh media komunitas, situs atau blog pribadi, mungkin masalah ini bisa dimaklumi bahkan diabaikan. Namun menjadi lain ceritanya karena jurnalisme warga yang dibahas dalam penelitian ini berada dalam naungan sebuah lembaga media resmi dan profesional.

Errol mencontohkan kejadian di bulan Oktober 2012. "Waktu itu ada laporan mobil hilang, terus ada yang menelepon melihat mobil itu. Jadi rupanya saking semangatnya, pendengar itu meyakinkan polisi untuk ikut mencari. Karena ciri-cirinya mirip, tapi setelah dicek semuanya, bukan.”

Jika terjadi kesalahan penyampaian informasi, SS tetap menyampaikan secara terbuka perihal informasi yang salah itu. SS juga memberikan informasi yang benar. Dengan demikian, khalayak tidak dibiarkan menelan informasi yang salah, karena ada keterangan yang menjelaskan kesalahan yang terjadi.

SS tidak pernah mengadakan training untuk pendengar tentang apakah jurnalistik itu, bagaimana cara meliput dan informasi di media. "Saya tidak punya penelitian yang komprehensif untuk ini, tetapi saya merasakan bahwa publik itu diam-diam mempelajari, bagaimana caranya laporan, apa yang dilaporkan," ungkap Errol. Dari mana publik belajar? Ternyata pola 'editing' yang selama ini dilakukan gatekeeper atau penyiar ditangkap juga oleh khalayak SS. Gatekeeper di SS menyunting informasi yang disampaikan pendengar dengan pola $5 \mathrm{~W}+1 \mathrm{H}$. Itulah yang lambat laun dipelajari oleh pendengar. Setelah 18 tahun sejak pertama kali menerima telepon dari pendengar, kini pendengar SS sendiri mulai memahami bagaimana seorang 'reporter' seharusnya melaporkan informasinya.

\section{KESIMPULAN}

Akurasi merupakan hal yang sangat signifikan bagi sebuah insitusi media massa. Terlebih lagi ketika institusi media massa tersebut menyediakan ruang bagi publik untuk membagikan informasi. Radio Suara Surabaya (SS) menyediakan ruang bagi pendengar untuk menyampaikan informasi dan ini disebut dengan jurnalisme warga. Demikian, akurasi merupakan konsep penting yang perlu dijaga oleh Radio Suara Surabaya mengingat SS memiliki beberapa informasi yang disampaikan oleh jurnalis warga.

Beberapa cara dilakukan oleh SS untuk menjaga akurasi informasi yang dilakukan oleh para jurnalis warga. Pertama, melakukan klarifikasi atas informasi yang disampaikan oleh jurnalis warga pada sumber yang kompeten. Kedua, SS menyarankan reporternya sendiri untuk turun ke lapangan, khususnya dalam hal informasi yang dianggap rawan atau membutuhkan pendalaman. Ketiga, SS membentuk bagian gatekeeper untuk memilah informasi mana yang bisa on air atau informasi mana yang masih harus dicek kebenarannya.

Menariknya, melalui kesempatan yang dibuka SS untuk para jurnalis warga, masyarakat yang berasal dari berbagai latar belakang belajar tentang pelaporan jurnalisme yang ideal.

\section{DAFTAR REFERENSI}

Bajari, Atwar dan Saragih, Sahala Tua (ed). 2011. Komunikasi Kontekstual: Teori dan Praktik Komunikasi Kontemporer. Bandung: Remaja Rosdakarya.

BH, Arifin. 2010. Suara Surabaya Bukan Radio. Surabaya: Suara Surabaya.

Blaagaard, Bollette B. 2013. Shifting Boundaries: Objectivity, Citizen Journalism and Tomorrow's Journalists. UK: Sage Publications.

Dewabrata, A.M. 2004. Kalimat Jurnalistik: Panduan Mencermati Penulisan Berita. Jakarta: Kompas

Fang, Irving. 1997. A History of Mass Communication Six Information Revolutions. USA: Focal Press.

Franklin, Bob, dkk. 2005. Key Concepts in Journalism Studies. London: SAGE Publications.

Kusumaningrat, Hikmat dan Kusumaningrat, Purnama. 2005. Jurnalistik: Teori dan Praktik. Bandung: Remaja Rosdakarya

Lewis, Seth C., Kaufhold, K., Lasorsa, Dominic L. 2009. Thinking about Citizen Journalism: Perspective on Participatory News Production at Community Newspaper.

Nock, M.K., Michel, B.D., Photos, V.I. 2007. Single Case Research Designs.

Oramahi, Hasan Asy'ari. 2003. Menulis Untuk Telinga: Sebuah Manual Penulisan Berita Radio. Jakarta: Gramedia Pustaka Utama

Pawito. 2007. Penelitian Komunikasi Kualitatif. Yogyakarta: LKiS. 
Prayudha, Harley. 2006. Penyiar: It's Not Just A Talk. Surabaya: Bayumedia Publishing.

Quinn, Stephen \& Lamble, Stephen. 2008. Online Newsgathering: Research \& Reporting for Journalism. USA: Focal Press.
Rich, Carole. 2010. Writing and Reporting News: A Coaching Method. Boston: Wadsworth.

Rivers, William, dkk. 2004. Media Massa dan Masyarakat Modern edisi kedua. Jakarta: Kencana.

Undang-Undang Dasar Negara Republik Indonesia tahun 1945. 